\title{
COMPARISON OF GYRFALCON DISTRIBUTIONS BETWEEN THE PALEARCTIC AND NEARCTIC
}

\author{
IVAN Pokrovsky ${ }^{1,3}$ AND Nicolas LeComte ${ }^{2}$ \\ ${ }^{1}$ A.N. Severtsov Institute of Ecology and Evolution, Russian Academy of Sciences, 33 Leninskij \\ prospekt,Moscow,119071,Russia.E-mail: ivanpok@mail.ru \\ ${ }^{2}$ Department of Arctic and Marine Biology, University of Troms $\phi$, NO-9037 Troms $\phi$, Norway \\ ${ }^{3}$ Current address: Shmitovsky pass 7-110, Moscow, 123100, Russia
}

\begin{abstract}
The Gyrfalcon (Falco rusticolus) is a circumpolar arctic raptor, using tree nests of other birds or cliff ledges for nesting. Its breeding distribution coincides with the distributions of its main prey, Rock Ptarmigan (Lagopus muta) and Willow Ptarmigan (L. lagopus). In the Palearctic, the range of the Gyrfalcon is relatively well studied except for the area between the Ob River and the Taimyr Peninsula in Russia. Uncertainty also existed for the Kamchatka Peninsula, which was regarded as a "possible, but yet proven" area for nesting until 2007 when Lobkov, with coauthors, published their data about nesting Gyrfalcons on the whole peninsula. Breeding Gyrfalcons in the Palearctic are mainly restricted to the forest-tundra zone and coastal rock cliffs, and they rely more often on tree nests than cliff nests, which is almost the reverse picture of the Nearctic, where Gyrfalcons are able to nest further north than Peregrines (Falco peregrinus), their direct competitors. The range overlap between these two top-predators is very small (ca. 10\%) in the Palearctic compared to the Nearctic, where overlap can be up to $30 \%$. We explore the reasons for that contrast, pointing out that overlap occurs mostly in areas where the two species of ptarmigan coexist (at the limit of the tree line, for example). In the context of climate change, with southern species predicted to move northward, it is still difficult to predict the outcome of potential increasing competition with Peregrines, considering that the Willow Ptarmigan is well known as a very flexible species under various climatic conditions. In Russia, perhaps the most pressing conservation issue is not the possible climatic impacts, but a heavy pressure of poaching of both adult and nestling Gyrfalcons, which has the potential to limit the population of this key predator. Received 9 September 2011, accepted 21 September 2011.
\end{abstract}

Pokrovsky, I., And N. Lecomte. 2011. Comparison of Gyrfalcon distributions between the Palearctic and Nearctic. Pages 65-70 in R. T. Watson, T. J. Cade, M. Fuller, G. Hunt, and E. Potapov (Eds.). Gyrfalcons and Ptarmigan in a Changing World, Volume I. The Peregrine Fund, Boise, Idaho, USA. http://dx.doi.org/10.4080/gpcw.2011.0107

Key words: Gyrfalcon, Falco rusticolus, Palearctic, Nearctic, poaching. 


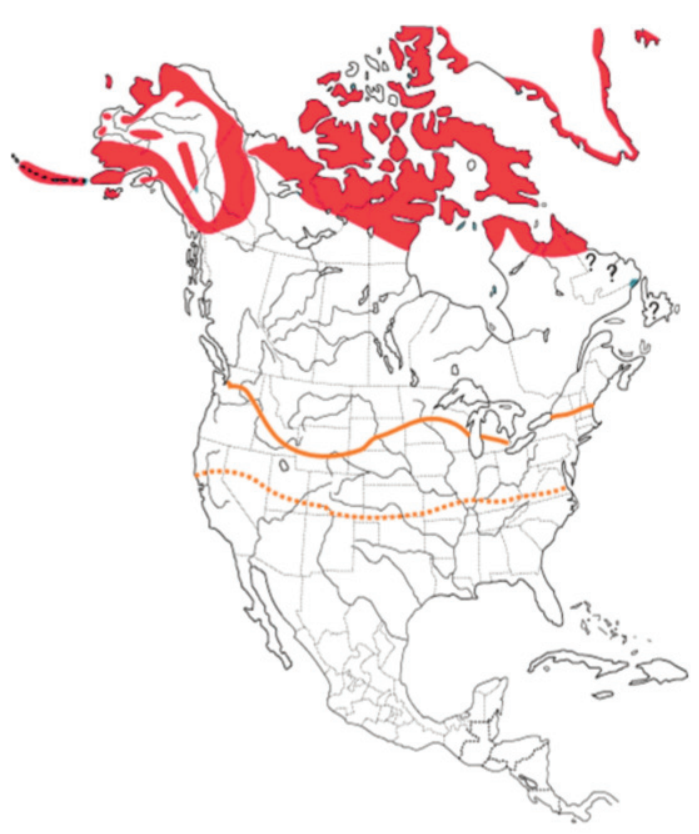

Figure 1. Breeding and wintering range of the Gyrfalcon in the Nearctic (Booms et al. 2008).

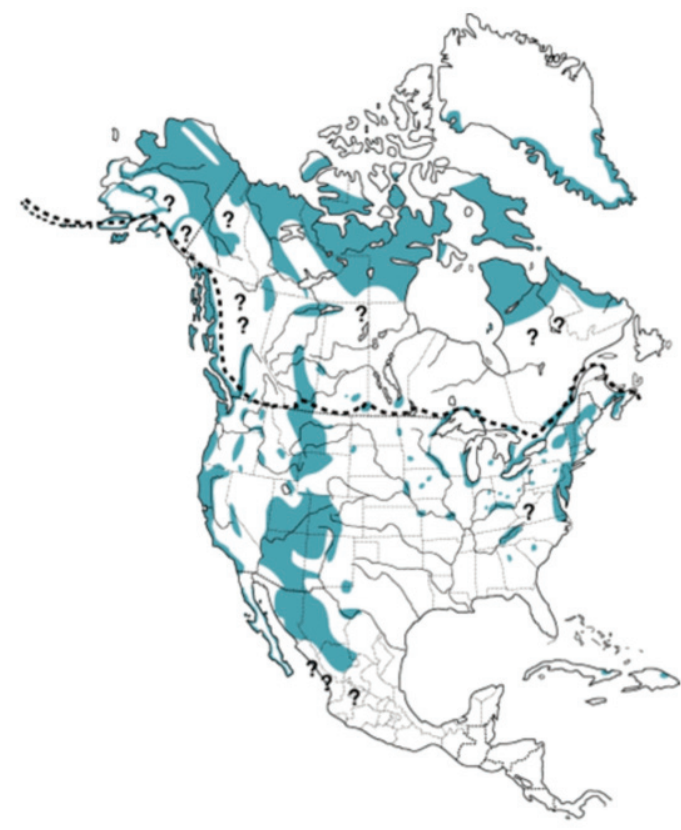

Figure 2. Distribution of the Peregrine Falcon in the Nearctic (White et al.2002).

\section{Human Related Differences}

Poaching.-The Gyrfalcon (Falco rusticolus) has been relatively well studied across its Palearctic distribution, especially in Iceland and Scandinavia. It has been intensively monitored in several parts of Russia, too, though the information gained has not always transferred to international knowledge outside of Russia. Within Russia, ornithologists have not strived to publish data about the Gyrfalcon's distribution because of the risk of revealing nest locations to poachers.

In their book about the Gyrfalcon, Potapov and Sale (2005) pinpointed gaps in knowledge over rather large sections of the Gyrfalcon's range in Russia, where information was lacking or unreliable. For example, there was no published and proven information clearly showing the presence of a breeding population on the Kamchatka Peninsula. Two years later, Lobkov and his colleagues (Lobkov et al. 2007 , 2011) published a paper showing that the whole of Kamchatka supports a stable breeding population of Gyrfalcons. Potapov and Sale (2005) indicated no breeding areas in a large part of western Siberia, yet several ornithologists from this region have observed Gyrfalcons on their nests (Pokrovskaya, pers. comm., Pokrovskaya and Tertitski 2011). The Lena River delta was described as inhabited by Gyrfalcons, but they were recorded there only later (Sokolov, unpubl. data). The northern part of the Kanin Peninsula (Kanin Kamen) is inhabited by Gyrfalcons (Pokrovsky, pers. obs.); yet, this region was not marked as a breeding area. There are more such examples across Russia; the authors know at least two ornithologists who have recorded Gyrfalcons breeding in areas described as non-breeding regions. They do not want to publish this information and have asked us not to share it. Likewise, some ornithology editors recommend that authors do not publish locations of Gyrfalcons' nests to reduce the risk of poaching. 
In contrast, nature monitoring and protection in Canada and the USA are well organized, and information about the Gyrfalcon's breeding distribution in the Nearctic is more widely shared. In the Palearctic, the greater proportion of the Gyrfalcon's breeding range is in Russia, where nature monitoring is poorly organized and poaching is well developed, likely as a result of an unstable economy. According to the Red List of Kamchatka (Lobkov 2006 with reference to Gordienko and Nechitailo 2000), Kamchatka poachers alone export a minimum of 40-50 Gyrfalcon pairs each year (without accounting for mortality during transportation). Over the last 30 years, the population of Gyrfalcons has declined by 2-3 times (Lobkov 1993, 2006, Lobkov et al. 2011). Observation suggests that the Gyrfalcon population has declined mainly in regions with good transport connections, which suggests a connection between the decline and the accessibility of regions to poachers. We predict that while poaching remains unchallenged in Russia, Gyrfalcon populations will continue to decline in regions with good transport, and remain little changed in regions with poorly developed transport systems. Also, information about Gyrfalcon distribution and abundance in Russia will remain unshared because ornithologists do not want to attract poachers to those regions. With such sensitivity to poaching, studies of Gyrfalcons in the Palearctic will lag behind others when measuring the effect of global perturbations, such as climate change.

Fur Trapping.-The second difference between the Nearctic and Palearctic, that is also directly linked to human activities, is fur trapping. Fur trapping was an intensive and well-organized industry, spread across vast geographical regions during most of the last Century. In many cases, Gyrfalcons and Snowy Owls (Bubo scandiacus) were trapped in fox traps set for Arctic Foxes (Vulpes lagopus) (Lobkov 2006, Artukhin 1991). Such bycatch, which affected all age-classes of these long-lived predators, likely drove population

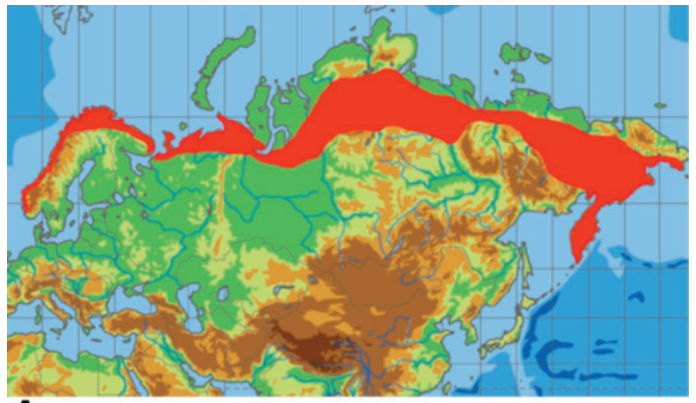

A

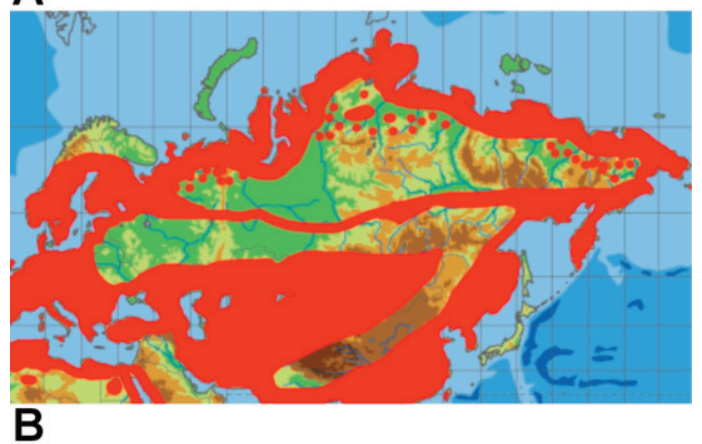

Figure 3. Breeding range of the Gyrfalcon (A) and Peregrine Falcon (B) in the Palearctic (http://steeman.org).

declines and change in distribution. After the fall of the Soviet Union, this industry practically collapsed in the northern regions, and now Gyrfalcon populations may be experiencing increased survival and population growth in those places. However, in some regions, people extensively hunt ptarmigan with snare traps, and still use foot traps to kill Gyrfalcons and Snowy Owls (the two most common species), and other raptors that feed on trapped ptarmigan.

\section{BiologiCAL DifFERENCES}

Most Northerly Falcon Species.-The Gyrfalcon is assumed to be the most northerly occurring falcon, though the Peregrine Falcon (Falco peregrinus) shares that claim in some literature. Distribution maps of the two species suggest that Gyrfalcons occur furthest north in the Nearctic (Figures 1 and 2) while Peregrines 

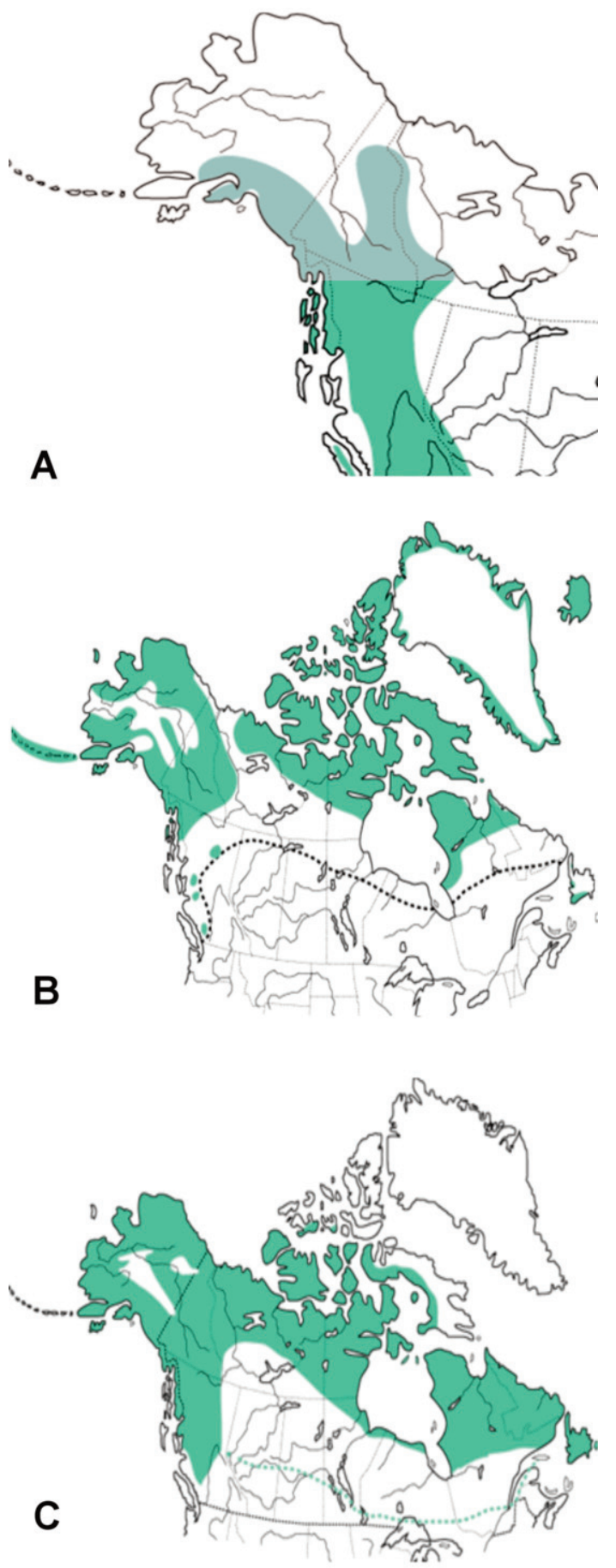

Figure 4. Distribution of White-tailed Ptarmigan (A), Rock Ptarmigan (B) and Willow Ptarmigan

(C) in the Nearctic (Braun et al. 1993, Hannon et al. 1998, Montgomerie et al. 2008). occur furthest north in the Palearctic (Figure 3 ). The extent of overlap of the breeding range of the two falcons can be up to $30 \%$ in the Nearctic (Figure 1 and 2), as is the overlap with ptarmigan distribution (Figure 4), where there is practically a perfect match between Gyrfalcon and ptarmigan ranges. In the Palearctic, Gyrfalcon and Peregrine Falcon ranges do overlap, but to a much lesser extent, and ptarmigan range over a larger area than the Gyrfalcon (ca. 10\%, Figure 5). Ptarmigan in the southern part of the Palearctic are less numerous than in the north, but it's still possible for Gyrfalcons to breed in the area to the south using nests in trees.

Nest Site Preferences. - The distribution of Gyrfalcons described above is consistent with a difference in nest site preferences between Nearctic and Palearctic regions. Palearctic Gyrfalcons in the southern part of their range (e.g., Schuchya River) nest mostly in trees (Mechnikova 2009, Mechnikova et al. 2011), and Nearctic Gyrfalcons nest mostly on rock cliffs. They also nest on earth ledges of high riverbanks in the Nearctic (Obst 1994), whereas such nest sites are unknown in the Palearctic.

In the Palearctic region, the Gyrfalcon's breeding range overlaps with Peregrines mostly in the west (Scandinavia and Kola Peninsula) and in the east (East Siberia) where rock cliffs exist. In the central region, Gyrfalcons breed mostly in the forest-tundra zone, while Peregrines breed mostly to the north of this area in one of the highest-density populations of this species in the world. In the Neartic region, we see the reverse, with Gyrfalcons breeding further north than Peregrines.

This raises the question, why do Gyrfalcons nest in the Palearctic in sites which the species does not use in the Nearctic? Are there genetic differences between these populations, are the behavioral differences between them based on tradition, or are the differences governed by resource availability and the Gyrfalcon's invariable response? 


\section{Conclusion}

We have described key differences in the ecology of the Gyrfalcons' populations in the Nearctic and the Palearctic. This dichotomy has diverse explanations and different roots. Understanding these differences is fundamental to developing a sound strategy for conservation of Gyrfalcons and investigating the potential effects of climate change on this species.

\section{Literature Cited}

ARTUKHIN, Y. B. 1991. Breeding avifauna of the Komandorskie Islands and impact of humans on its status. Pages 99-137 in Natural Resources of the Komandorskie Islands. MSU Press, Moscow, Russia (in Russian).

Booms, T. L., T. J. CAde, AND N. J. Clum. 2008. Gyrfalcon (Falco rusticolus). In A. Poole (Ed.). The Birds of North America Online. Cornell Laboratory of Ornithology, Ithaca, New York, USA. Retrieved from the Birds of North America Online database: http://bna.birds.cornell.edu/bna/ species/114

Braun, C. E., K. Martin, and L. A. Robb. 1993. White-tailed Ptarmigan (Lagopus leucura). In A. Poole (Ed.). The Birds of North America Online. Cornell Laboratory of Ornithology, Ithaca, New York, USA. Retrieved from the Birds of North America Online database: http://bna.birds.cornell. edu/bna/species/068

Gordienko, T. A., AND Y. I. Nechitailov. 2000. Problems of raptor conservation in Kamchatka. Pages 111-113 in Conservation of Biodiversity in Kamchatka and Circumjacent Sea. Materials of the Scientific Regional Conference. Petropavlovsk-Kamchatsky, Russia, April 11-12, 2000 (in Russian).

Hannon, S. J., P. K. Eason, And K. Martin. 1998. Willow Ptarmigan (Lagopus lagopus). In A. Poole (Ed.). The Birds of North America Online. Cornell Laboratory of Ornithology, Ithaca, New York, USA.

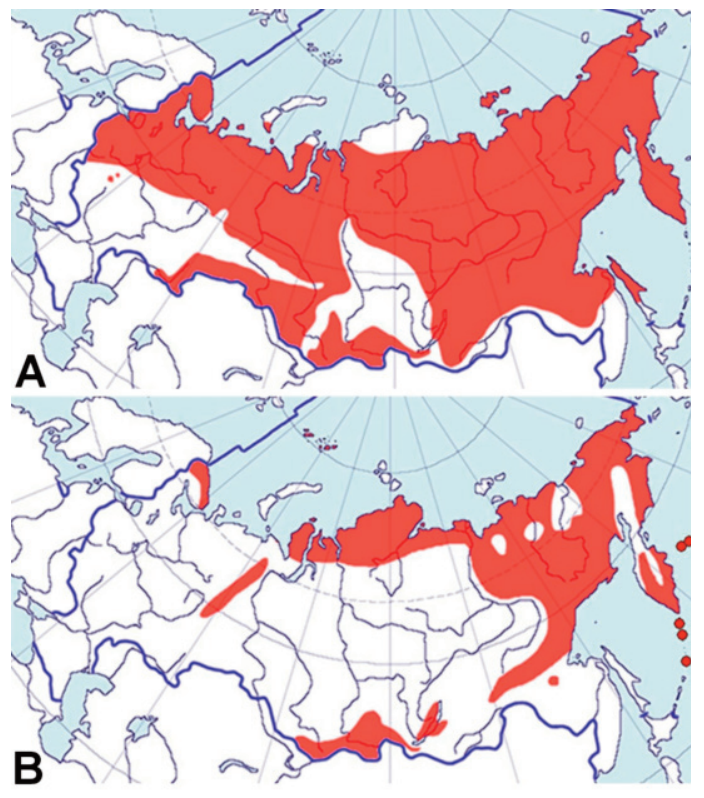

Figure 5. Distribution of Willow Ptarmigan (A) and Rock Ptarmigan (B) in the Palearctic (http://www.birds-online.ru).

Retrieved from the Birds of North America Online database: http://bna.birds.cornell. edu/bna/species/369

Loвкоv, E. G. 1993. Rare and endangered species of Kamchatka. Regional Notes 8:142-156.

Loвkov, E. G. 2006. Gyrfalcon. Pages 153156 in A. M. Tokranov (Ed.). Red List of Kamchatka. Kamchatsky pechatny dvor publishing house, Petropavlovsk-Kamchatsky, Russia (in Russian).

Lobkov, E. G., Yu. N. Gerasimov, And A. V. Gorovenko. 2007. On the status of the Gyrfalcon (Falco rusticolus) population in Kamchatka, the Russian Far East. Ornithologia 34(1):5-35 (in Russian).

Lobkov, E., Yu. Gerasimov, AND A. Gorovenko. 2011. Status of the Kamchatka Gyrfalcon (Falco rusticolus) population and factors affecting it. In R. T. Watson, T. J. Cade, M. Fuller, G. Hunt, and E. Potapov (Eds.). Gyrfalcons and Ptarmigan in a Changing World. The Peregrine 
Fund, Boise, Idaho, USA. http://dx.doi. org/10.4080/gpcw.2011.0127

Mechnikova, S. A. 2009. Raptors of the Southern Yamal. Ph.D. dissertation. Moscow Pedagogical State University. Moscow, Russia (in Russian).

Mechnikova, S., M. Romanov, and N. KudRYAVTSEV. 2011. Change in numbers and nesting ecology of the Gyrfalcon in the Yamal Peninsula, Russia, from 1981 to 2010. In R. T. Watson, T. J. Cade, M. Fuller, G. Hunt, and E. Potapov (Eds.). Gyrfalcons and Ptarmigan in a Changing World. The Peregrine Fund, Boise, Idaho, USA. http://dx.doi.org/10.4080/gpcw.2011 . 0220

Montgomerie, R., And K. Holder. 2008. Rock Ptarmigan (Lagopus muta). In A. Poole (Ed.). The Birds of North America Online. Cornell Laboratory of Ornithology, Ithaca, New York, USA. Retrieved from the Birds of North America Online database: http://bna.birds.cornell.edu/bna/ species/051
OвSт, J. 1994. Tree-nesting by the Gyrfalcon (Falco rusticolus) in the western Canadian Arctic. Journal of Raptor Research 28:4-8.

Pokrovskaya, I., AND G. Tertitski. 2011. Number and distribution of Gyrfalcons on the West Siberian Plain. In R. T. Watson, T. J. Cade, M. Fuller, G. Hunt, and E. Potapov (Eds.). Gyrfalcons and Ptarmigan in a Changing World. The Peregrine Fund, Boise, Idaho, USA. http://dx.doi.org/ 10.4080/gpcw.2011.0305

Potapov, E., And R. SAle. 2005. The Gyrfalcon. Yale University Press, New Haven, Connecticut, USA.

White, C. M., N. J. Clum, T. J. Cade, And W. G. Hunt. 2002. Peregrine Falcon (Falco peregrinus). In A. Poole (Ed.). The Birds of North America Online. Cornell Laboratory of Ornithology, Ithaca, New York, USA. Retrieved from the Birds of North America Online database: http://bna.birds.cornell. edu/bna/species/660 